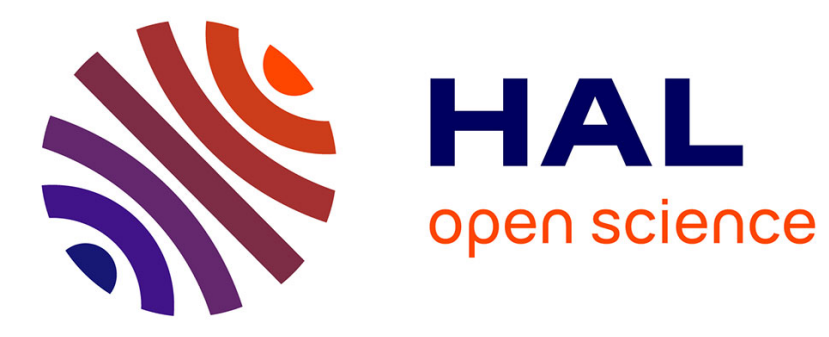

\title{
Synthesis, Crystal Structure, and Stability of Cubic Li7-xLa3Zr2-xBixO12
}

\author{
Reinhard Wagner, Daniel Rettenwander, Guenther J. Redhammer, Gerold \\ Tippelt, Gebhard Sabathi, Maurizio E. Musso, Bernhard Stanje, Martin \\ Wilkening, Emmanuelle Suard, Georg Amthauer
}

\section{To cite this version:}

Reinhard Wagner, Daniel Rettenwander, Guenther J. Redhammer, Gerold Tippelt, Gebhard Sabathi, et al.. Synthesis, Crystal Structure, and Stability of Cubic Li7-xLa3Zr2-xBixO12. Inorganic Chemistry, 2016, 55 (23), pp.12211-12219. 10.1021/acs.inorgchem.6b01825 . hal-01691854

\section{HAL Id: hal-01691854 https://hal.science/hal-01691854}

Submitted on 24 Jan 2018

HAL is a multi-disciplinary open access archive for the deposit and dissemination of scientific research documents, whether they are published or not. The documents may come from teaching and research institutions in France or abroad, or from public or private research centers.
L'archive ouverte pluridisciplinaire HAL, est destinée au dépôt et à la diffusion de documents scientifiques de niveau recherche, publiés ou non, émanant des établissements d'enseignement et de recherche français ou étrangers, des laboratoires publics ou privés. 


\section{Synthesis, Crystal Structure, and Stability of Cubic $\mathrm{Li}_{7-x} \mathrm{La}_{3} \mathrm{Zr}_{2-x} \mathrm{Bi}_{x} \mathrm{O}_{12}$}

Reinhard Wagner, ${ }^{*}{ }^{\dagger}$ Daniel Rettenwander, ${ }^{\dagger, \|}$ Günther J. Redhammer, ${ }^{\dagger}$ Gerold Tippelt, ${ }^{\dagger}$ Gebhard Sabathi, ${ }^{\dagger}$ Maurizio E. Musso, ${ }^{\dagger}$ Bernhard Stanje, ${ }^{\ddagger}$ Martin Wilkening, ${ }^{\ddagger}$ Emmanuelle Suard, ${ }^{\S}$ and Georg Amthauer ${ }^{\dagger}$

${ }^{\dagger}$ Department of Chemistry and Physics of Materials, University of Salzburg, 5020 Salzburg, Austria

${ }^{*}$ Christian Doppler Laboratory for Lithium Batteries, Institute for Chemistry and Technology of Materials, Graz University of Technology, 8010 Graz, Austria

${ }^{\S}$ Diffraction Group, Institut Laue-Langevin (ILL), 71 avenue des Martyrs, 38000 Grenoble, France

\section{Supporting Information}

ABSTRACT: Li oxide garnets are among the most promising candidates for solidstate electrolytes in novel $\mathrm{Li}$ ion and $\mathrm{Li}$ metal based battery concepts. Cubic $\mathrm{Li}_{7} \mathrm{La}_{3} \mathrm{Zr}_{2} \mathrm{O}_{12}$ stabilized by a partial substitution of $\mathrm{Zr}^{4+}$ by $\mathrm{Bi}^{5+}$ has not been the focus of research yet, despite the fact that $\mathrm{Bi}^{5+}$ would be a cost-effective alternative to other stabilizing cations such as $\mathrm{Nb}^{5+}$ and $\mathrm{Ta}^{5+}$. In this study, $\mathrm{Li}_{7-x} \mathrm{La}_{3} \mathrm{Zr}_{2-x} \mathrm{Bi}_{x} \mathrm{O}_{12}$ $(x=0.10,0.20, \ldots, 1.00)$ was prepared by a low-temperature solid-state synthesis route. The samples have been characterized by a rich portfolio of techniques, including scanning electron microscopy, X-ray powder diffraction, neutron powder diffraction, Raman spectroscopy, and ${ }^{7} \mathrm{Li}$ NMR spectroscopy. Pure-phase cubic

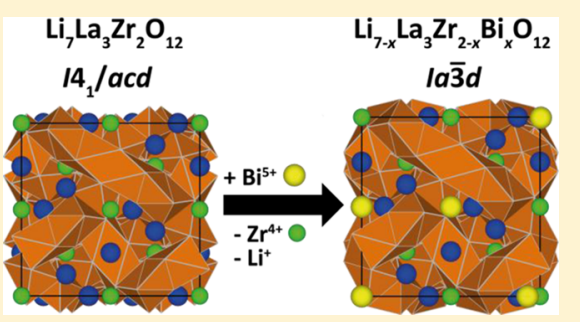
garnet samples were obtained for $x \geq 0.20$. The introduction of $\mathrm{Bi}^{5+}$ leads to an increase in the unit-cell parameters. Samples are sensitive to air, which causes the formation of $\mathrm{LiOH}$ and $\mathrm{Li}_{2} \mathrm{CO}_{3}$ and the protonation of the garnet phase, leading to a further increase in the unit-cell parameters. The incorporation of $\mathrm{Bi}^{5+}$ on the octahedral $16 a$ site was confirmed by Raman spectroscopy. ${ }^{7} \mathrm{Li}$ NMR spectroscopy shows that fast $\mathrm{Li}$ ion dynamics are only observed for samples with high $\mathrm{Bi}^{5+}$ contents.

\section{INTRODUCTION}

Li stuffed oxide garnets have received much scientific attention as fast $\mathrm{Li}$ ion conductors. In particular, cubic $\mathrm{Li}_{7} \mathrm{La}_{3} \mathrm{Zr}_{2} \mathrm{O}_{12}$ (LLZO) with its excellent chemical and thermal stability as well as its electrochemical inertness against $\mathrm{Li}$ metal is perfectly suited to be used as solid electrolyte and protecting layer in the next generation of all-solid-state $\mathrm{Li}$ ion and $\mathrm{Li}$ metal battery concepts. $^{1,2}$

Pure LLZO occurs in at least two structural polymorphs: a low-temperature tetragonal (space group $I 4_{1} /$ acd) and a cubic "high-temperature" phase (space group $I a \overline{3} d$ ). ${ }^{1,3}$ Since the $\mathrm{Li}$ ion conductivity of the cubic phase is at least 2 orders of magnitude higher $\left(10^{-4}\right.$ to $10^{-3} \mathrm{~S} \mathrm{~cm}^{-1}$ at room temperature) in comparison to the tetragonal phase, the stabilization of the cubic phase at room temperature is highly needed. ${ }^{3-5}$

Fortunately, the cubic polymorph can be stabilized at room temperature by doping with supervalent cations such as $\mathrm{Al}^{3+2,5-8} \mathrm{Fe}^{3+}, 9,10$ and $\mathrm{Ga}^{3+}, 11-14$ which are incorporated on the 4-fold coordinated $24 d / 96 h$ positions replacing $\mathrm{Li}^{+}, \mathrm{Ce}^{4+}$ replacing $\mathrm{La}^{3+}$ on the 8 -fold coordinated $24 \mathrm{c}$ position, ${ }^{15}$ and $\mathrm{Mo}^{6+},{ }^{6,17} \mathrm{Nb}^{5+18} \mathrm{Ta}^{5+},{ }^{12,13,19-21} \mathrm{Sb}^{5+22}, \mathrm{Te}^{6+}, \mathrm{W}^{6+},{ }^{64}$ and $\mathrm{Y}^{3+25}$ replacing $\mathrm{Zr}^{4+}$ at the octahedrally coordinated $16 a$ position. It was recently shown by Xia et al. that a stabilization of the cubic $I a \overline{3} d$ modification can also be achieved by a partial substitution of $\mathrm{Zr}^{4+}$ with $\mathrm{Bi}^{5+}$; the end member $\mathrm{Li}_{5} \mathrm{La}_{3} \mathrm{Bi}_{2} \mathrm{O}_{12}$ (LLBO) was already described by Murugan et al. and further discussed in several other studies. ${ }^{26-30}$
The Li ion conductivity of LLZO at room temperature is still 1-2 orders of magnitude lower than that of widely used liquid electrolytes or other superionic conductors: e.g., $\mathrm{Li}_{10} \mathrm{GeP}_{2} \mathrm{~S}_{12}$, and $\mathrm{Li}_{1+x} \mathrm{Al}_{x} \mathrm{Ti}_{2-x}\left(\mathrm{PO}_{4}\right)_{3}$ (LATP). ${ }^{31-33}$ Hence, there is great interest in further improving its $\mathrm{Li}$ ion conductivity by microstructural and crystal chemical engineering.

The Li ion conductivity of cubic LLZO depends on various factors, such as, e.g., (i) amount of mobile charge carriers, (ii) vacancy concentration, (iii) coordination number of $\mathrm{Li}$ ions, (iv) strength and length of $\mathrm{Li}-\mathrm{O}$ bond, and (v) microstructure of samples. ${ }^{34-36}$

These factors are strongly influenced by the cations that are added to stabilize the cubic Ia $\overline{3} d$ modification of LLZO. Since $\mathrm{Bi}^{5+}$ has a larger ionic radius in comparison to $\mathrm{Zr}^{4+}$, the unit-cell parameter $a_{0}$ for $\mathrm{Li}_{5} \mathrm{La}_{3} \mathrm{Bi}_{2} \mathrm{O}_{12}$ (LLBO) is significantly larger in comparison to that of LLZO stabilized with other dopant elements ( 13.065 vs $12.97 \AA))^{27,37}$

We decided to study the LLZO-LLBO solid solution, in order to systematically vary $a_{0}$ and the $\mathrm{Li}$ content. Therefore, we synthesized $\mathrm{Li}_{7-x} \mathrm{La}_{3} \mathrm{Zr}_{2-x} \mathrm{Bi}_{x} \mathrm{O}_{12}$ (LLZBO) with varying $\mathrm{Bi}$ contents $(x=0.10,0.20, \ldots, 1.00)$ by solid-state synthesis at comparatively low temperatures. By means of X-ray powder diffraction (XRPD) and neutron powder diffraction (NPD) we studied the exchangeability of $\mathrm{Zr}^{4+}$ by $\mathrm{Bi}^{5+}$ in the LLZO-LLBO solid solution (LLZBO) and its stabilization effect on the cubic

Received: July 28, 2016

Published: November 15, 2016 

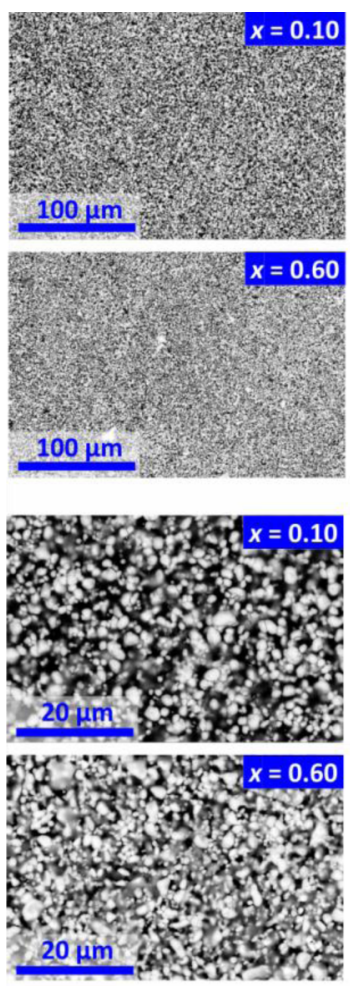
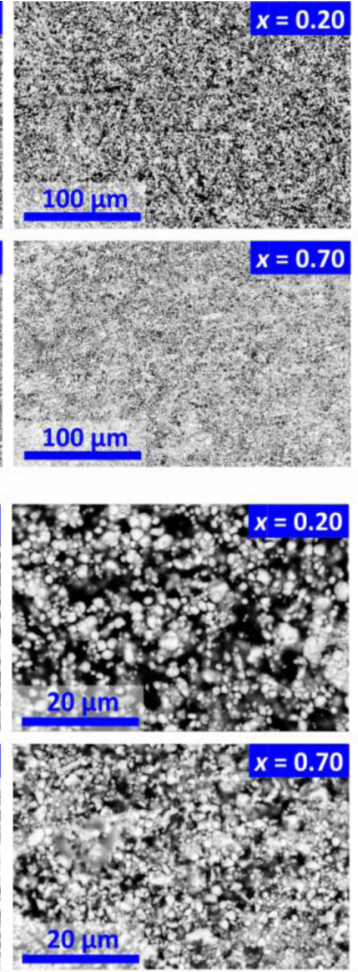
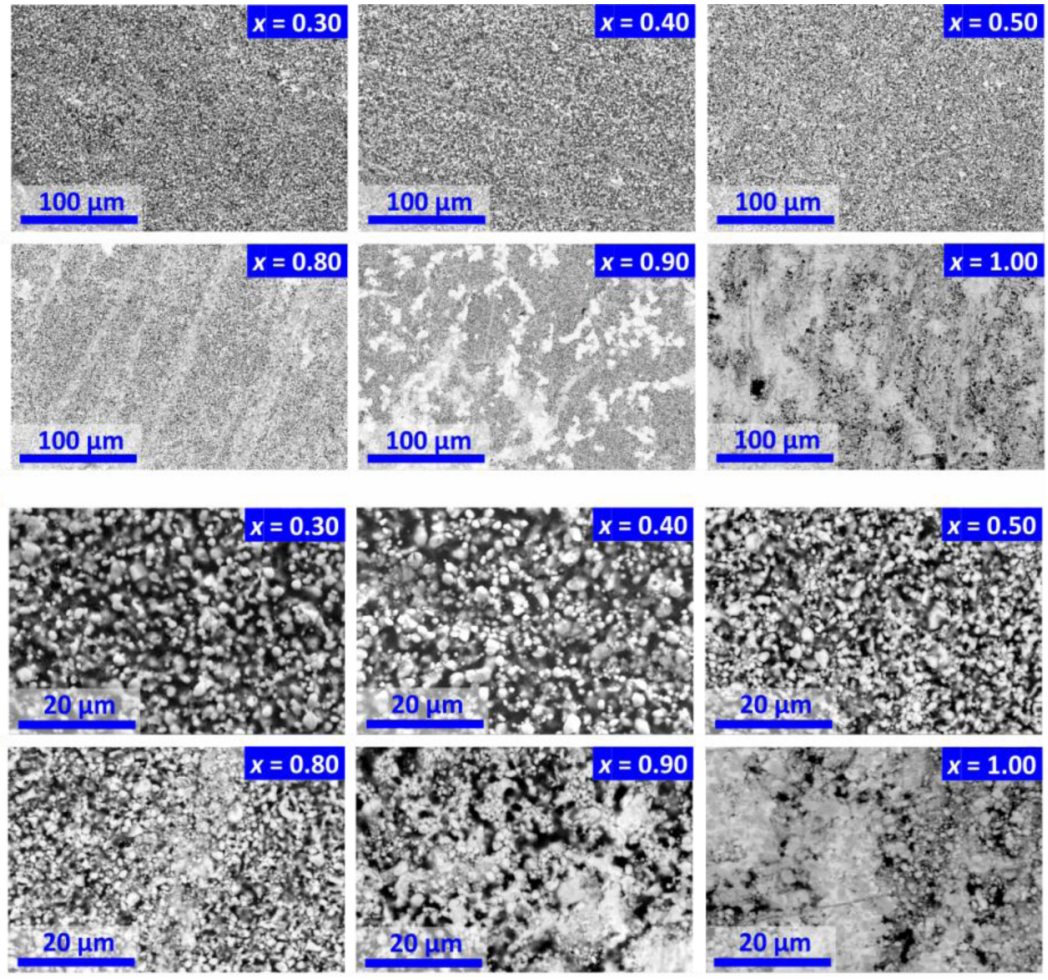

Figure 1. SEM-BSE images of $\mathrm{Li}_{7-x} \mathrm{La}_{3} \mathrm{Zr}_{2-x} \mathrm{Bi}_{x} \mathrm{O}_{12}$ with different magnifications.

LLZO structure. The influence of $\mathrm{Bi}^{5+}$ on the microstructure was evaluated by scanning electron microscopy (SEM) using backscattered electrons (BSE) and secondary electrons (SE). Energy-dispersive X-ray spectroscopy (EDX) measurements were performed to investigate the chemical composition of samples with regard to $\mathrm{La}, \mathrm{Zr}$, and $\mathrm{Bi}$. Raman spectroscopy was applied to obtain information on the site occupation behavior of $\mathrm{Bi}^{5+}$. Finally, ${ }^{7} \mathrm{Li}$ nuclear magnetic resonance (NMR) line shape measurements were employed to study $\mathrm{Li}$ ion dynamics as a function of $a_{0}$ and composition.

\section{EXPERIMENTAL SECTION}

2.1. Synthesis. A series of $\mathrm{Li}_{7-x} \mathrm{La}_{3} \mathrm{Zr}_{2-x} \mathrm{Bi}_{x} \mathrm{O}_{12}$ garnets with intended mole fractions of $\mathrm{Bi}\left(x_{\text {int }}\right)=0.10,0.20, \ldots, 1.00$ was synthesized by sintering in air. The starting materials were $\mathrm{Li}_{2} \mathrm{CO}_{3}$ (99\%, Merck), $\mathrm{La}_{2} \mathrm{O}_{3}$ (99.99\%, Roth), $\mathrm{ZrO}_{2}$ (99.0\%, Roth), and $\mathrm{Bi}_{2} \mathrm{O}_{3}$ (99.0\%, Merck). The reagents were weighed out in their intended stoichiometric proportions with an excess of $10 \mathrm{wt} \%$ of $\mathrm{Li}_{2} \mathrm{CO}_{3}$ to compensate for the loss of $\mathrm{Li}_{2} \mathrm{O}$ during sintering. The reagents were mixed in an agate mortar and then cold-pressed into pellets with the help of a uniaxial press. The pellets were put into an alumina crucible. To avoid contamination with $\mathrm{Al}^{3+}$ from the crucible, the samples were placed on a pellet of pure LLZO. During the first sintering step, the samples were heated to $850{ }^{\circ} \mathrm{C}$ at a rate of $5{ }^{\circ} \mathrm{C} \mathrm{min}{ }^{-1}$ and calcinated for $4 \mathrm{~h}$. The resulting pellets were then removed from the furnace, ground in an agate mortar, and ball-milled for $1 \mathrm{~h}$ in isopropyl alcohol (FRITSCH Pulverisette 7, $800 \mathrm{rpm}, 2 \mathrm{~mm} \mathrm{ZrO}_{2}$ balls). After drying in air, the powder was again cold-pressed into pellets. The sample pellets were again placed on a pellet of pure LLZO and then put into an alumina crucible. The final sintering step was performed at $850{ }^{\circ} \mathrm{C}$ for $8 \mathrm{~h}$ in air. Small fragments of the sintered pellets were ground in an agate mortar and used for the XRPD, NPD, and NMR investigations. Material used for the last two characterization methods was stored under Ar. For SEM analysis, polycrystalline chips from the sample pellets were embedded in epoxy resin. The surface was ground and then polished using diamond paste. Relative densities of unaltered samples have been measured by pycnometry. The influence of the $\mathrm{Bi}^{5+}$ content and the unit-cell parameters on the theoretical densities has been considered by using theoretical densities obtained from Rietveld refinement of XRPD data. In addition, the presence of extra phases has also been taken into consideration.

2.2. SEM. Scanning electron microscopy investigations were performed using a Zeiss Ultra Plus device to determine the grain size and grain morphology of the samples. In particular, we put emphasis on the investigation of the phase composition and the chemical homogeneity, i.e. the distribution, of $\mathrm{La}, \mathrm{Zr}$, and $\mathrm{Bi}$, using a backscattered electron detector (BSE) and energy-dispersive X-ray spectroscopy (EDX) measurements with an acceleration voltage of 20 $\mathrm{kV}$.

2.3. XRPD. X-ray powder diffraction patterns were recorded with a Bruker D8 Advance DaVinci Design diffractometer with a Lynxeye solid-state detector using $\mathrm{Cu} \mathrm{K} \alpha$ radiation to characterize the synthetic products in terms of all phases present and to determine the symmetry of the garnet. Data were collected in the range $10^{\circ} \leq 2 \theta \leq 80^{\circ}$. For a precise determination of the unit-cell parameter $a_{0}$, separate measurements were performed with addition of a silicon standard with a well-known lattice constant $\left(a_{0}=5.43088 \AA\right)$ to each sample. XRPD patterns were recorded on fresh samples immediately after synthesis as well as on samples that were stored in air for 1 and 3 weeks, respectively. The unit-cell parameter $a_{0}$ was determined by Rietveld refinement using the program Topas V2.1 (Bruker).

2.4. NPD. Neutron powder diffraction measurements were performed at the Institut Laue-Langevin (ILL) in Grenoble, France. Powder diffraction data were collected at room temperature in constant wavelength mode with $\lambda=1.594 \AA$ at the $\mathrm{D} 2 \mathrm{~B}$ diffractometer. Experiments were performed with a step width of $0.04^{\circ}$ in the range $5.8^{\circ} \leq 2 \theta \leq 159.7^{\circ}$. Data treatment and refinement were carried out with the FULLPROF suite of programs. ${ }^{38}$ In all data evaluations, the $\mathrm{La},(\mathrm{Zr}+\mathrm{Bi})$, and $\mathrm{O}$ atom positions were refined using anisotropic atomic displacement parameters; the atomic displacement factor for the Lil positions was refined isotropically while that of $\mathrm{Li} 2$ was set to 3.5 to avoid large correlations with the occupation factor. Site occupancies on $\mathrm{Li}$ sites were then allowed to refine unconstrained and $(\mathrm{Zr}+\mathrm{Bi})$ was fixed to full occupation of this site; however, the relative 


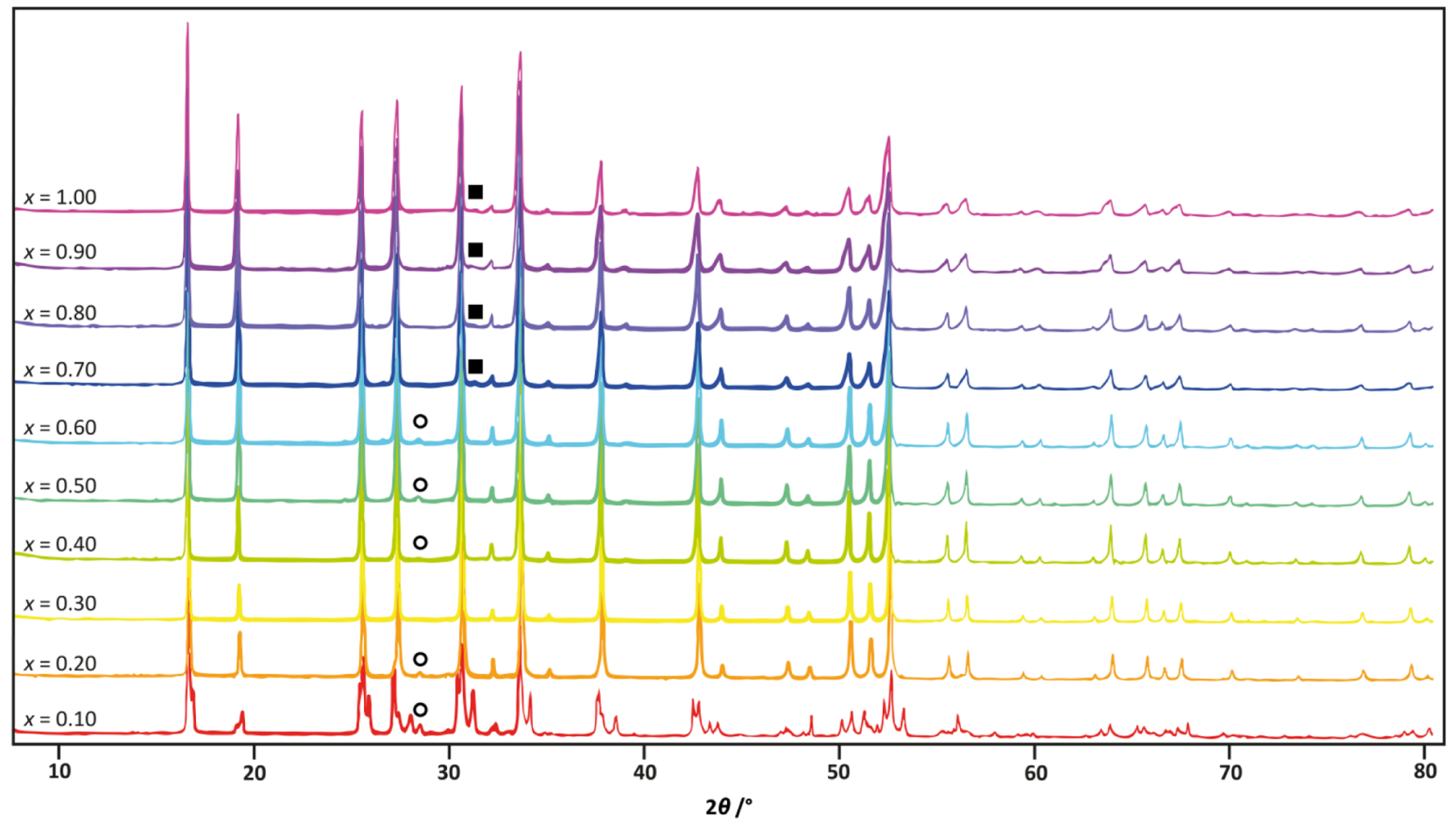

Figure 2. XRPD patterns of as-synthesized $\mathrm{Li}_{7-x} \mathrm{La}_{3} \mathrm{Zr}_{2-x} \mathrm{Bi}_{x} \mathrm{O}_{12}$ samples. Peaks at $2 \theta=28.6^{\circ}$, marked with open circles, are attributed to small amounts of $\mathrm{La}_{2} \mathrm{Zr}_{2} \mathrm{O}_{7}$, while peaks at $2 \theta=31.8^{\circ}$, marked with black squares, are attributed to $\mathrm{Li}_{2} \mathrm{CO}_{3}$.

Table 1. Refined $\mathrm{Bi}^{5+}$ Content $x_{\text {ref }}$, Relative Density, and Unit-Cell Parameters $a_{0}$ of LLZBO Derived from Rietveld Refinement of XRPD Data Collected Immediately after Synthesis as well as after Air Exposure for 1 and 3 Weeks, Respectively

\begin{tabular}{cccccc} 
& & & \multicolumn{2}{c}{$a_{0}(\AA)$} \\
\cline { 3 - 6 }$x_{\text {int }}$ & $x_{\text {ref }}$ & rel density $(\%)$ & as synthesized & after 1 week & after 3 weeks \\
0.10 & 0.155 & 69 & $13.00265(57)$ & $13.01189(23)$ & $13.05982(40)$ \\
0.20 & 0.187 & 71 & $13.00222(27)$ & $13.03072(31)$ & $13.06170(43)$ \\
0.30 & 0.283 & 72 & $13.00547(48)$ & $13.04424(33)$ & $13.06736(39)$ \\
0.40 & 0.404 & 68 & $13.01373(53)$ & $13.04441(28)$ & $13.07248(47)$ \\
0.50 & 0.495 & 70 & $13.01896(72)$ & $13.05463(25)$ & $13.08688(20)$ \\
0.60 & 0.602 & 72 & $13.02295(17)$ & $13.05933(33)$ & $13.08769(12)$ \\
0.70 & 0.708 & 74 & $13.02912(29)$ & $13.07479(23)$ & $13.08501(18)$ \\
0.80 & 0.806 & 80 & $13.03307(31)$ & $13.07065(23)$ & $13.08578(15)$ \\
0.90 & 0.893 & 85 & $13.03699(37)$ & $13.07647(23)$ & $13.08517(21)$ \\
1.00 & 1.000 & 89 & $13.04522(31)$ & $13.06803(33)$ & $13.08144(25)$
\end{tabular}

amounts of $\mathrm{Bi}$ and $\mathrm{Zr}$ were allowed to refine freely. The results for $\mathrm{Bi}$ and $\mathrm{Zr}$ occupancies agree well with those of XRPD refinements.

2.5. Raman Spectroscopy. Raman spectra of the sample pellets were collected at room temperature with a Thermo Scientific DXR Raman microscope using a $10 \mathrm{~mW}$ depolarized internal laser light source with an excitation wavelength of $780 \mathrm{~nm}$. The Raman microscope was equipped with a high-resolution grating, allowing the collection of Raman spectra from 50 to $1800 \mathrm{~cm}^{-1}$ with a spatial resolution (fwhm) of $2 \mathrm{~cm}^{-1}$.

2.6. ${ }^{7} \mathrm{Li}$ NMR Lines. For the ${ }^{7} \mathrm{Li}$ NMR line shape measurements under static, i.e., nonrotating, conditions the samples were ground in an agate mortar and fire-sealed under vacuum in DURAN glass ampules (ca. $4 \mathrm{~cm}$ in length and $0.5 \mathrm{~cm}$ in diameter) to permanently protect the powders from any moisture or air. ${ }^{7} \mathrm{Li}$ NMR measurements were performed using a Bruker Avance III spectrometer, which was connected to a shimmed cryomagnet (Bruker) with a nominal external magnetic field of $B_{0}=7.04 \mathrm{~T}$; the ${ }^{7} \mathrm{Li}$ resonance frequency $\omega_{0} / 2 \pi$ was 116.4 MHz. ${ }^{7} \mathrm{Li}$ NMR spectra were recorded with the saturation recovery pulse sequence. In our case, this sequence contained $10 \pi / 2$ pulses to destroy any longitudinal magnetization $M$. After a constant waiting time, the magnetization recovered was flipped into the $(x y)^{\prime}$ plane via a final $\pi / 2$ pulse to detect the free induction decay. Fourier transformation and subsequent phase correction led to the spectra shown in this work.

\section{RESULTS}

3.1. Crystal Size, Morphology, and Chemical Composition As Seen by SEM and SEM-EDX. After the final sintering step, the sample pellets have a yellow color, the intensity of the color rising with increasing Bi content. Polished samples were examined by SEM-BSE. Figure 1 shows SEMBSE images of samples with different Bi contents. The grain size of the samples is around $1-3 \mu \mathrm{m}$. Single grains show an isometric shape. The $\mathrm{Bi}$ concentration does not have a significant effect on the grain size, but an improved densification is noted for samples with higher $\mathrm{Bi}$ concentrations. SEM-EDX measurements of $\mathrm{La}, \mathrm{Zr}$, and Bi show that 
sample compositions for these elements are well in agreement with the intended stoichiometries. Very frequently, a finegrained phase was found between single LLZBO grains. This phase is interpreted as a mixture of $\mathrm{LiOH}$ and $\mathrm{Li}_{2} \mathrm{CO}_{3}$ that formed during processing and polishing of samples.

3.2. Phase Composition and Unit-Cell Parameters As Seen via XRPD. The XRPD patterns of the $\mathrm{Li}_{7-x} \mathrm{La}_{3} \mathrm{Zr}_{2-x} \mathrm{Bi}_{x} \mathrm{O}_{12}\left(x_{\text {int }}=0.10-1.00\right)$ are shown in Figure 2. The phase compositions of the samples were evaluated by Rietveld analysis. All samples exhibit reflections indicating cubic Ia $\overline{3} d$ symmetry. For the sample with $x_{\text {int }}=0.10$, Rietveld refinement shows about $66 \%$ of tetragonal LLZO and $34 \%$ of cubic garnet. Some samples show a small peak at $2 \theta=28.6^{\circ}(d$ $=3.12 \AA$ ), which can be attributed to $\mathrm{La}_{2} \mathrm{Zr}_{2} \mathrm{O}_{7}$, while other samples show a reflection at $2 \theta=31.8^{\circ}(d=2.81 \AA$ ) , indicating the presence of small amounts of $\mathrm{Li}_{2} \mathrm{CO}_{3}$. If $\mathrm{Zr}$ and $\mathrm{Bi}$ contents on the octahedral $16 a$ site are allowed to refine freely during Rietveld refinement, the refined Bi contents $x_{\text {ref }}$ obtained from these refinements are well in accordance with the intended $\mathrm{Bi}$ contents $x_{\text {int }}$ (see Table 1 ). Reflections show a relatively broad peak shape, especially at high $2 \theta$ angles.

As shown in Figure 3 and Table 1, the unit-cell parameters of LLZBO samples increase with increasing Bi content. For low Bi

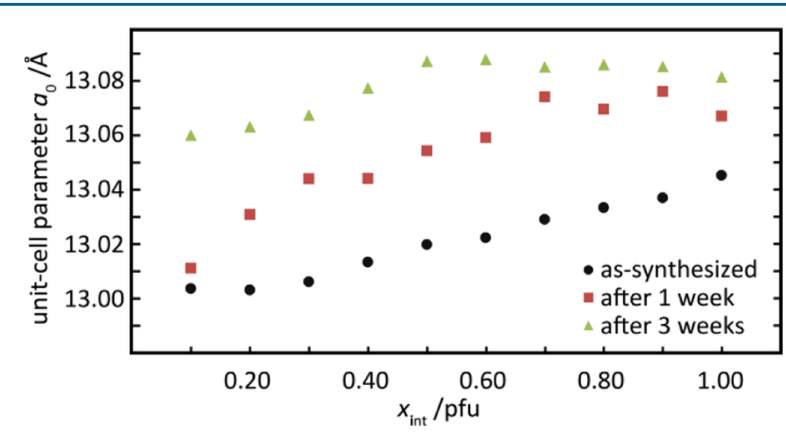

Figure 3. Unit-cell parameters $a_{0}$ of as-synthesized LLZBO samples (black dots) and LLZBO samples after storage under air for 1 week (red squares) and 3 weeks (green triangles), respectively.

concentrations, the lattice parameter $a_{0}$ is around $13.00 \AA$ and increases up to $13.04 \AA$ for the sample with $x_{\text {int }}=1.00$. This observation is in agreement with Vegard's law, as 6-fold coordinated $\mathrm{Bi}^{5+}$ shows an ionic radius of $0.76 \AA$, which is larger than that of 6 -fold coordinated $\mathrm{Zr}^{4+}(0.72 \AA) .{ }^{37}$ The correlation between the intended $\mathrm{Bi}$ content $x_{\text {int }}$ and the unit-cell parameter $a_{0}$ of LLZBO can be expressed by a simple linear regression: $a_{0}=0.0494 x_{\text {int }}+12.994$. A comparison with other studies on LLZBO shows that the unit-cell parameters obtained in this work are systematically higher; however, the slope of the linear regression is in agreement with other studies on LLZBO and LLBO. ${ }^{26-28}$ The comparatively large unit-cell parameter might not only be attributed to the increase caused by the substitution of $\mathrm{Zr}^{4+}$ by $\mathrm{Bi}^{5+}$; it also seems to be related to a partial protonation of LLZBO due to a reaction of the garnet phase with moisture from the air, as this behavior was described for similar compounds as well. ${ }^{39,40}$ This is also indicated by the presence of $\mathrm{Li}_{2} \mathrm{CO}_{3}$ as mentioned above, as $\mathrm{Li}_{2} \mathrm{CO}_{3}$ can result from the reaction of $\mathrm{CO}_{2}$ from air with $\mathrm{LiOH}$, which is a side product of the protonation of LLZO-type materials. ${ }^{41-43}$

3.3. Stability of LLZBO in Air. To study the stability of LLZBO in air, samples were ground in an agate mortar and stored under air for 1 and 3 weeks, respectively. XRPD measurements including a silicon standard were performed to investigate the formation of secondary phases as well as to determine the unit-cell parameters. The evolution of the unitcell parameters as a function of the Bi content and the duration of exposure is shown in Figure 3 and Table 1. It is clearly visible that the unit-cell parameters increase if samples are stored under air. This increase is attributed to the protonation of the garnet phase, which was also reported by other studies on LLZO. ${ }^{39,40}$ The protonation reaction also causes the formation of $\mathrm{Li}_{2} \mathrm{CO}_{3}$. The presence of small amounts of $\mathrm{Li}_{2} \mathrm{CO}_{3}$ in aged samples was confirmed by XRPD measurements due to the presence of an additional reflection at $d=4.16 \AA$. The peak width of LLZO reflections, especially at high $2 \theta$ angles, increases even further in comparison to XRPD patterns of fresh samples; however, attempts to perform a fit using two different LLZBO garnets with different unit-cell parameters did not lead to a significant improvement. Attempts were also made to perform a structural refinement using the $I \overline{4} 3 d$ model, which was recently reported for protonated $\mathrm{Li}$ oxide garnets and LLZO garnets stabilized with certain cations such as $\mathrm{Ga}^{3+}$ and $\mathrm{Fe}^{3+} \cdot{ }^{40,44-47}$ As the characteristic 310 reflection of space group $I \overline{4} 3 d$, which appears at $d=4.10 \AA\left(2 \theta=21.6^{\circ}\right)$ for LLZO garnets with a unit-cell parameter of $12.97 \AA$, would shift to larger $d$ values due to the increasing unit-cell parameters of LLZBO, it might be possible that the additional reflection at $d$ $=4.16 \AA\left(2 \theta=21.35^{\circ}\right)$ is related to the phase transformation to the $I \overline{4} 3 d$ space group. Rietveld refinement showed that, even for strongly protonated LLZBO samples with large unit-cell parameters of $13.08 \AA$, this characteristic 310 reflection of space group $I \overline{4} 3 d$ would be located at $d=4.138 \AA\left(2 \theta=21.45^{\circ}\right)$. Therefore, the additional reflection at $d=4.16 \AA\left(2 \theta=21.35^{\circ}\right)$ is attributed to the 110 reflection of $\mathrm{Li}_{2} \mathrm{CO}_{3}$ and not to a LLZBO garnet phase with space group $I \overline{4} 3 \mathrm{~d}$. In addition, the evolution of a small peak at $2 \theta=31.8^{\circ}(d=2.81 \AA)$ can also be related to $\mathrm{Li}_{2} \mathrm{CO}_{3}$. The presence of $\mathrm{Li}_{2} \mathrm{CO}_{3}$ was also confirmed by evaluation of NPD measurements as well as by Raman spectroscopy.

3.4. NPD. Results of neutron powder diffraction generally confirmed the results obtained by XRPD. Refinement results of 2 different NPD measurements are shown in Figures S1 and S2 in the Supporting Information. As the samples were stored under an Ar atmosphere, NPD samples were only slightly affected by protonation and aging, in comparison to samples from XRPD measurements. The $\mathrm{Li}_{2} \mathrm{CO}_{3}$ contents were quantified for all LLZBO samples, yielding about $2 \% \mathrm{Li}_{2} \mathrm{CO}_{3}$. Small contents of $\mathrm{LiOH}$ were found as well. As determined by XRPD, the sample with $x_{\text {int }}=0.10$ still shows both tetragonal $I 4_{1} / a c d$ and cubic $I a \overline{3} d$ garnet modifications. In contrast to the evaluation of XRPD data, a model with two different cubic (space group $I a \overline{3} d$ ) LLZBO phases was used for the evaluation of NPD data of samples with $x_{\text {int }} \geq 0.30$, as the data quality and resolution of data obtained from NPD are better than those obtained from XRPD. This model consists of an LLZBO phase that is unaffected or only slightly affected by protonation and a second LLZBO phase which is strongly affected by protonation on the $96 h$ site, therefore showing a larger unit-cell parameter. For this second phase only $\mathrm{H}^{+}$was assumed to occupy $96 h$; fractional atomic coordinates are close to those reported recently for protonated LLZO with space group $I a \overline{3} d .^{48}$ In the unprotonated material, the Li content decreases with increasing Bi content, for both the Li1 and Li2 sites to similar extents; however, data overlap is large so that no additional detailed structural parameters can be extracted. Unit-cell parameters of unprotonated and protonated LLZBO phases of different 
samples obtained by Rietveld refinements of NPD data are shown in Table $S 1$ and Figure $S 3$ in the Supporting Information; the corresponding structural data of selected samples are given in Table S2 in the Supporting Information. Unit-cell parameter values for unprotonated LLZBO samples are similar to values of as-synthesized values obtained from XPRD; while the unit-cell parameters of protonated LLZBO phases are similar to XRPD-derived values of samples that have been stored in air for 1 week. The discontinuity of the unit-cell parameter between samples with $x_{\text {int }}=0.70$ and $x_{\text {int }}=0.80$ might be related to different alteration stages that could not be resolved. Rietveld refinements yield protonated garnet contents between $22 \%$ and $34 \%$.

3.5. Raman Spectroscopy. Raman spectra of LLZBO samples are shown in Figure 4.

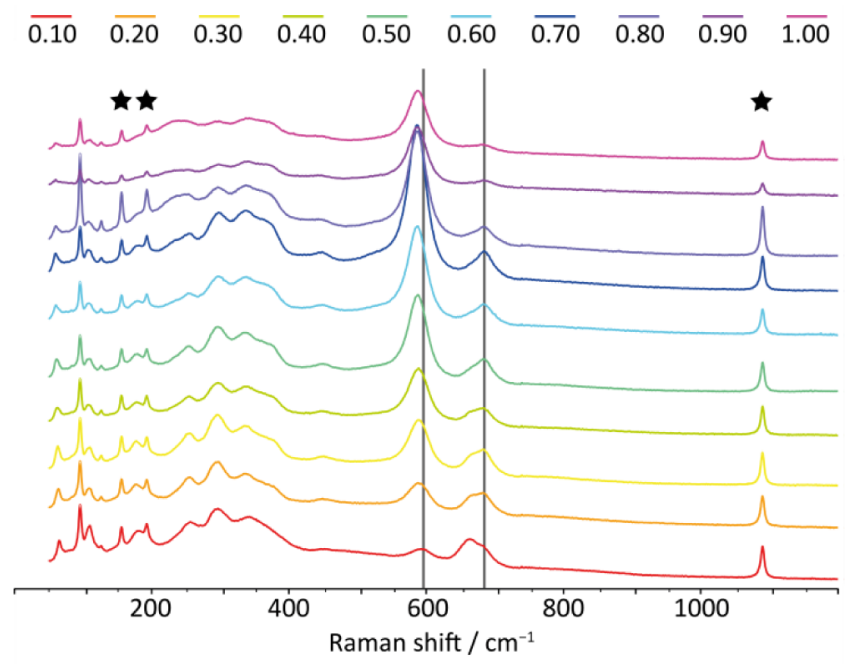

Figure 4. Raman spectra of $\mathrm{Li}_{7-x} \mathrm{La}_{3} \mathrm{Zr}_{2-x} \mathrm{Bi}_{x} \mathrm{O}_{12}$ samples $(x=0.10$, $0.20, \ldots, 1.00)$. Bands at 156,195 , and $1090 \mathrm{~cm}^{-1}$, marked with stars, are attributed to $\mathrm{Li}_{2} \mathrm{CO}_{3}$. Two vertical lines have been added to highlight the shifting of bands.

In general, the obtained spectra show a good coincidence with other spectra of cubic LLZO stabilized with different aliovalent cations. ${ }^{16,19,43,49,50}$ In addition to the characteristic LLZO bands, additional bands at 156,195 , and $1090 \mathrm{~cm}^{-1}$ were observed for all samples. These bands can be assigned to $\mathrm{Li}_{2} \mathrm{CO}_{3} \cdot{ }^{41,51-53}$ Considering the evolution of the Raman spectra depending on the variation in the $\mathrm{Zr} / \mathrm{Bi}$ ratio, the most prominent features are two bands at $\sim 590$ and $\sim 650$ $\mathrm{cm}^{-1}$, respectively, which show a distinct trend, depending on the Bi content. The band at $\sim 590 \mathrm{~cm}^{-1}$ gets more intense and slightly shifts to lower wavenumbers with increasing Bi content, whereas at the same time the intensity of the band at $\sim 650$ $\mathrm{cm}^{-1}$ decreases and the band shifts toward higher wavenumbers. Bands in this region are interpreted as $\mathrm{M}-\mathrm{O}$ breathing modes of the octahedral $16 a$ position. Mukhopadhyay et al. observed that the $\mathrm{Zr}-\mathrm{O}$ associated band appears at $640 \mathrm{~cm}^{-1}$, whereas a $\mathrm{Ta}-\mathrm{O}$ associated band is present at 720 $\mathrm{cm}^{-1}{ }^{19}$ This effect was due to a shorter bond length of Ta-O in comparison to $\mathrm{Zr}-\mathrm{O}$. Rettenwander et al. observed an analogous effect for $\mathrm{Li}_{7-2 x} \mathrm{La}_{3} \mathrm{Zr}_{2-x} \mathrm{Mo}^{6+}{ }_{x} \mathrm{O}_{12}$, as they observed the appearance and intensity increase of a band at $\sim 770 \mathrm{~cm}^{-1}$ with increasing Mo content of the garnet. ${ }^{16}$ The evolution of the Raman spectra of LLZBO can be explained similarly. The progression of the band at $590 \mathrm{~cm}^{-1}$ is considered as an effect of the extended bond length of $\mathrm{Bi}-\mathrm{O}$ bonds in comparison to $\mathrm{Zr}-\mathrm{O}$ bonds, as the ionic radius of $\mathrm{Bi}^{5+}$ is larger than that of $\mathrm{Zr}^{4+}$, resulting in the appearance of a band at smaller wavenumbers, which slightly shifts to lower wavenumbers with increasing $\mathrm{Bi}$ contents, in accordance with the slightly increasing unit-cell parameters of the LLZBO samples with increasing $\mathrm{Bi}$ contents. Another interesting feature can be observed in the low-wavenumber region between 200 and 400 $\mathrm{cm}^{-1}$, in particular for samples with high $\mathrm{Bi}^{5+}$ contents $\left(x_{\text {int }}=\right.$ $0.80-1.00)$. Raman spectra show a broadening of the bands in this region. The broad bands were also found in other studies and have been attributed to disorder caused by the migration of highly mobile $\mathrm{Li}^{+}$ions along the $\mathrm{Li}^{+}$diffusion pathways. ${ }^{43,49,54}$ These observations are well in accordance with results of ${ }^{7} \mathrm{Li}$ NMR spectroscopy.

3.6. Static ${ }^{7}$ Li NMR Spectra: Line Narrowing. NMR line shapes of the quadrupole ${ }^{7} \mathrm{Li}$ nucleus (spin quantum number $I$ $=3 / 2$ ) are sensitive to both local and long-range Li ion hopping processes. In addition to possible quadrupolar effects, at low temperatures dipolar interactions broaden the spectra; such interactions are averaged with increasing diffusivity of the spincarrying ions. Thus, by a comparison of line shapes of samples with different compositions at the same temperature, preliminary information on $\mathrm{Li}$ ion dynamics can be deduced. For this purpose, static ${ }^{7} \mathrm{Li} \mathrm{NMR}$ spectra of $\mathrm{Li}_{7-x} \mathrm{La}_{3} \mathrm{Zr}_{2-x} \mathrm{Bi}_{x} \mathrm{O}_{12}$ $\left(x_{\text {int }}=0.10-1.00\right)$ were recorded at three different temperatures at a Larmor frequency of $\omega_{0} / 2 \pi=116.4 \mathrm{MHz}$ (see Figures 5 and 6).

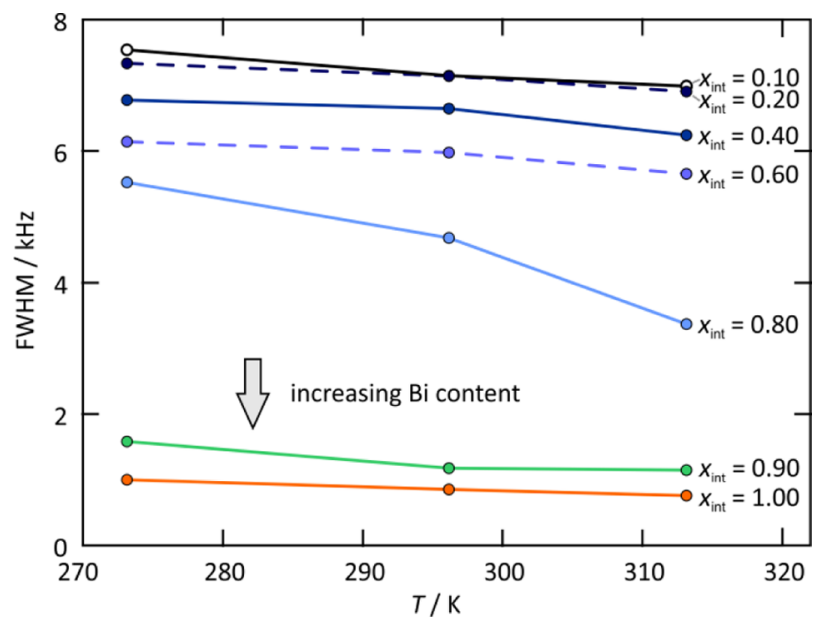

Figure 5. ${ }^{7} \mathrm{Li}$ NMR line width (fwhm = full width at half-maximum, $116 \mathrm{MHz}$ ) as a function of temperature $T$. The lines are drawn to guide the eye. The higher the $\mathrm{Bi}$ content, the faster the $\mathrm{Li}$ ions exchange among the crystallographic sites in the garnets. See the text for further explanations.

While at a Bi content of $x_{i n t}>0.60$ the line width (full width at half-maximum), when read off at $273 \mathrm{~K}$, ranges from approximately 6 to ca. $7 \mathrm{kHz}$, it clearly drops down to only 850 $\mathrm{Hz}$ when $x_{\text {int }}=1.00$ is reached (Figure 5). Importantly, already at $x_{\text {int }}=0.80$ a narrow top superimposes the broad Gaussianshaped line which characterizes the central line of the other samples (see Figure 6). The narrow component is the first indication of a fast-diffusing spin subensemble having access to jump pathways with low activation barriers. At $x_{\text {int }}=1.00$ the narrow line governs almost the whole NMR spectrum (Figure 6), which reveals that almost all $\mathrm{Li}$ ions participate in fast ion 


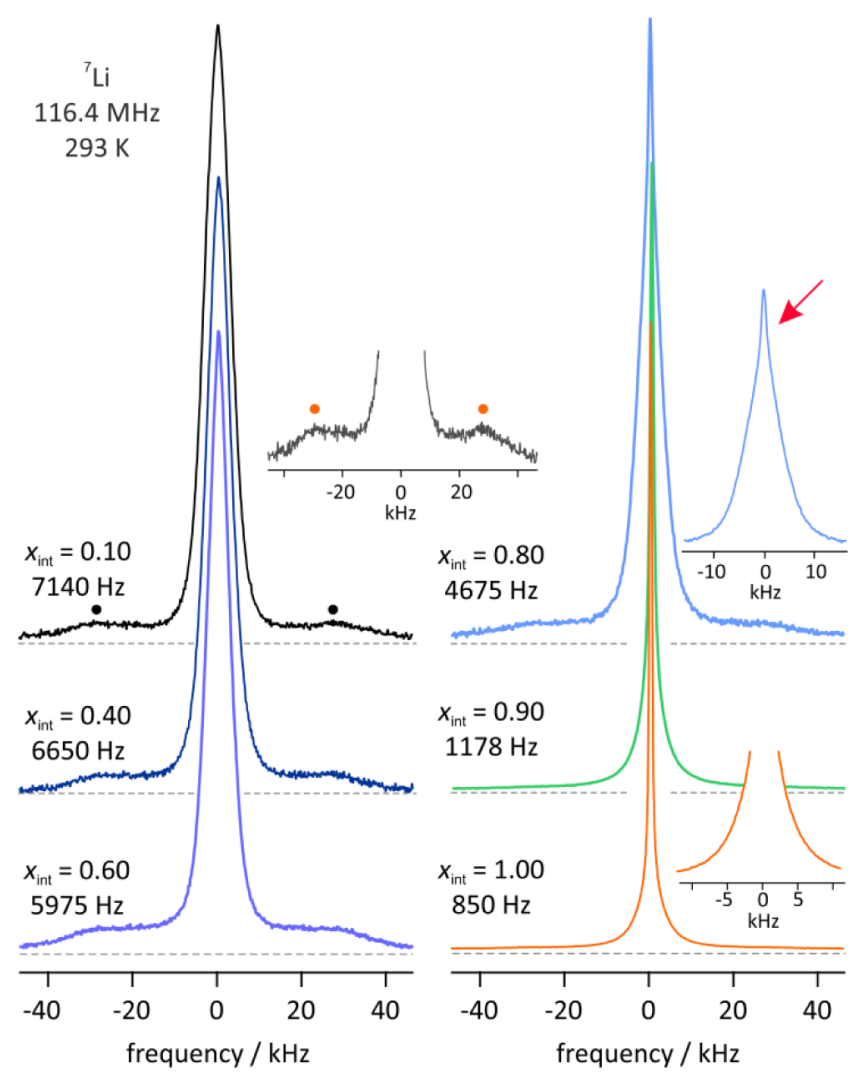

Figure 6. Static ${ }^{7} \mathrm{Li}$ NMR spectra of $\mathrm{Li}_{7-x} \mathrm{La}_{3} \mathrm{Zr}_{2-x} \mathrm{Bi}_{x} \mathrm{O}_{12}\left(x_{\text {int }}=0.10-\right.$ 1.00 ) recorded at $\omega_{0} / 2 \pi=116.4 \mathrm{MHz}$ and $273 \mathrm{~K}$. Full line narrowing is reached at $x_{\text {int }}=0.90$; at this composition, quadrupole intensities are significantly averaged due to Li jump processes. The sample with $x_{\text {int }}=$ 0.80 already reveals a two-component line shape representing fast and slow $\mathrm{Li}$ ions. See the text for further explanation.

exchange. The central line of the sample with $x_{\text {int }}=1.00$ does not change further with increasing temperature; at $T>273 \mathrm{~K}$ the shape of the spectra remains unchanged, demonstrating that the extreme narrowing regime was already reached at $273 \mathrm{~K}$ (Figure 5). On consideration of a rigid-lattice line width, $\nu_{\mathrm{r} \text {, }}$, on the order of a few kilohertz, at $273 \mathrm{~K}$ (and also higher temperatures) the Li jump rate $\tau^{-1}$ is estimated to be at least of the same order of magnitude. This is in contrast to the samples with $x_{\text {int }}>0.60$ : up to $T \approx 310 \mathrm{~K}$ only the rigid-lattice regime is detected (Figure 5). The corresponding mean Li jump rate turns out to be much lower than $\nu_{\mathrm{rl}}$ and, hence, has no effect on the line width. Hence, significant Li ion dynamics, able to average homonuclear dipole-dipole couplings, is only observed for samples with large amounts of $\mathrm{Bi}$ incorporated. The change in rigid-lattice line width with increasing $x_{\text {int }}$ cf. the samples with $x_{\text {int }}<0.60$, presumably reflects a decreasing $\mathrm{Li}-\mathrm{Li}$ distance to which $\nu_{\mathrm{rl}}$ is sensitive.

$\mathrm{Li}$ diffusivity averages not only magnetic dipolar but also electric quadrupolar interactions. These effects result from the interaction of the quadrupole moment of the Li nucleus with a nonvanishing electric field gradient at the nuclear site. In contrast to the situation with no electric field gradient, the four Zeeman levels are perturbed so that, in the case of a polycrystalline sample, a powder pattern shows up (Figure 6). $\mathrm{Li}$ diffusivity also affects this pattern, leading to averaged quadrupole satellite lines at sufficiently high temperatures. For $x_{\text {int }}<0.80$ the NMR lines reveal distinct patterns (see also the inset shown for the sample with $x_{\text {int }}=0.10$ in Figure 6). The $90^{\circ}$ singularities, marked in Figure 6 with dots, point to coupling constants in the order of $60 \mathrm{kHz}$. The larger the $x_{\text {int }}$ value, the higher the $\mathrm{Li}$ exchange among the electrically different Li sites. Sufficiently fast exchange causes the pattern to vanish. At $T$ values much higher than those covered in this study, the emergence of a new, fully averaged quadrupole powder pattern is expected, characterized by a reduced coupling constant.

\section{DISCUSSION}

The main goal of this study is to observe the influence of a partial substitution of $\mathrm{Zr}^{4+}$ by $\mathrm{Bi}^{5+}$ in LLZO and the stabilization of the cubic phase. Pure-phase cubic samples were obtained for Bi contents $x_{\text {int }} \geq 0.20$, which is consistent with the results of previous studies. ${ }^{26}$ It has to be noted that pure-phase cubic garnet samples are obtained by comparatively low $\mathrm{Bi}$ contents, as much higher dopant concentrations are needed if other substituting cations, such as $\mathrm{Ta}^{5+}$ and $\mathrm{Nb}^{5+}$, are used as substituents for $\mathrm{Zr}^{4+} .50,55$ Rietveld refinement of XRPD data confirms a systematic increase of the unit-cell parameter with increasing $\mathrm{Bi}^{5+}$ content; additionally, the increase of the unit-cell parameter is partially caused by a protonation of the garnet phase. The increase of the unit-cell parameter due to protonation and the observation of $\mathrm{Li}_{2} \mathrm{CO}_{3}$ from NPD as well as from Raman spectroscopy indicate that LLZBO is unstable in air. As NPD samples, which have been stored under Ar directly after the synthesis, already show the first signs of protonation, the protonation might already start during the cooling of samples in the furnace. Reactions with $\mathrm{H}_{2} \mathrm{O}$ and $\mathrm{CO}_{2}$ from the air cause the formation of $\mathrm{LiOH}$ and $\mathrm{Li}_{2} \mathrm{CO}_{3}$ and lead to a protonation of the garnet, which has negative effects on the ionic conductivity. ${ }^{40-44,55-59}$ Due to the small grain size of the samples and the high porosity of the pellets, both being side effects of the low sintering temperature, the samples provide a large surface for interactions with air. LLZBO samples from this study seem to be very prone to these reactions, as the increase of the lattice parameter was observed after less than 1 week of storage in air. Even samples characterized by XRPD immediately after synthesis show indications for the aging process mentioned above. $\mathrm{Li}_{2} \mathrm{CO}_{3}$ was partially also documented from XRPD measurements of samples immediately after synthesis; however, small concentrations of $\mathrm{Li}_{2} \mathrm{CO}_{3}$ are hardly observable by XRPD. LLZBO samples stored under Ar were less affected by the aging process, as the unit-cell parameters obtained by NPD, where samples have been stored under $\mathrm{Ar}$, were lower than those obtained from XRPD. However, even NPD samples showed indications for the aging process such as the formation of $\mathrm{Li}_{2} \mathrm{CO}_{3}$ and the presence of protonated LLZBO. Therefore, the exposure of LLZBO to air should be strictly avoided. In addition, an enhancement of the density of LLZBO samples would also be beneficial, as the surface area of LLZBO grains available for interaction with air would decrease. An increase in the density of LLZBO samples will also have positive effects on the $\mathrm{Li}$ ion conductivity.

Results from ${ }^{7} \mathrm{Li}$ NMR spectroscopy show that fast $\mathrm{Li}$ ion diffusivity for LLZBO is only achieved for high Bi contents. As the samples have been stored under Ar, the samples have not been significantly affected by protonation and the results show a very clear trend as a function of the Bi content. Xia et al. studied the $\mathrm{Li}$ ion conductivity of cubic LLZBO with $x=0.20$ and obtained a Li ion conductivity of $2.6 \times 10^{-5} \mathrm{~S} \mathrm{~cm}^{-1}$. ${ }^{26}$ The results from this study indicate that higher $\mathrm{Li}$ ion conductivities might be achieved by using samples with higher Bi contents. 
Also for Ta-stabilized LLZO, the highest conductivities were reported for Ta contents of 0.60 atoms per formula unit. ${ }^{60}$ The results of Xia et al. also show that an increase of the density of samples, either by higher sintering temperatures or by the introduction of $\mathrm{Al}^{3+}$ that acts as a sintering aid, are beneficial for the $\mathrm{Li}$ ion conductivity. As stated above, an improved preparation route for LLZBO will be necessary to obtain satisfying electrochemical performances. As $\mathrm{Ga}^{3+}$ seems to be an even more effective sintering aid for LLZO in comparison to $\mathrm{Al}^{3+}$, it may be worth preparing and studying Ga-bearing LLZBO samples as well.

\section{CONCLUSIONS}

The cubic modification of LLZO can be stabilized by a substitution of $\mathrm{Zr}^{4+}$ with $\mathrm{Bi}^{5+}$. Samples prepared by a lowtemperature synthesis route show a broad peak shape in XRPD and are sensitive to moisture and $\mathrm{CO}_{2}$ content in air, which leads to the protonation of LLZBO and the formation of $\mathrm{LiOH}$ and $\mathrm{Li}_{2} \mathrm{CO}_{3}$. This aging has been proven by NPD and Raman spectroscopy as well. The incorporation of $\mathrm{Bi}$ into the LLZO structure leads to the evolution of an additional band in the Raman spectra at $\sim 590 \mathrm{~cm}^{-1}$. ${ }^{7} \mathrm{Li}$ NMR spectroscopy shows that fast translational $\mathrm{Li}$ ion dynamics are only observed for samples with large amounts of $\mathrm{Bi}$ incorporated.

\section{ASSOCIATED CONTENT}

\section{S Supporting Information}

The Supporting Information is available free of charge on the ACS Publications website at DOI: 10.1021/acs.inorgchem.6b01825.

Results of Rietveld refinement of NPD measurements of samples with $x_{\text {int }}=0.20$ and $x_{\text {int }}=0.90$, respectively, unitcell parameters of LLZBO obtained from Rietveld refinement of NPD measurements, unit-cell parameters of LLZBO obtained by Rietveld refinement of NPD measurements, and structural models of samples with $x_{\text {int }}$ $=0.20$ and $x_{\text {int }}=0.80$ derived from Rietveld refinement of NPD data (PDF)

\section{AUTHOR INFORMATION}

\section{Corresponding Author}

*E-mail for R.W.: Reinhard.Wagner@sbg.ac.at.

\section{Present Address}

"Center for Materials Science and Engineering, Massachusetts Institute of Technology, Cambridge, Massachusetts 02139, United States

\section{Notes}

The authors declare no competing financial interest.

\section{ACKNOWLEDGMENTS}

This study was supported by the Austrian Science Fund (FWF), project number P25702. The authors thank the ILL for allocation of neutron beam time and financial support.

\section{REFERENCES}

(1) Murugan, R.; Thangadurai, V.; Weppner, W. Fast lithium ion conduction in garnet-type $\mathrm{Li}_{7} \mathrm{La}_{3} \mathrm{Zr}_{2} \mathrm{O}_{12}$. Angew. Chem., Int. Ed. 2007, $46,7778-7781$.

(2) Geiger, C. A.; Alekseev, E.; Lazic, B.; Fisch, M.; Armbruster, T.; Langner, R.; Fechtelkord, M.; Kim, N.; Pettke, T.; Weppner, W. Crystal Chemistry and Stability of " $\mathrm{Li}_{7} \mathrm{La}_{3} \mathrm{Zr}_{2} \mathrm{O}_{12}$ " Garnet: A Fast Lithium-Ion Conductor. Inorg. Chem. 2011, 50, 1089-1097.
(3) Awaka, J.; Kijima, N.; Hayakawa, H.; Akimoto, J. Synthesis and structure analysis of tetragonal $\mathrm{Li}_{7} \mathrm{La}_{3} \mathrm{Zr}_{2} \mathrm{O}_{12}$ with the garnet-related type structure. J. Solid State Chem. 2009, 182, 2046-2052.

(4) Thangadurai, V.; Narayanan, S.; Pinzaru, D. Garnet-type solidstate fast $\mathrm{Li}$ ion conductors for $\mathrm{Li}$ batteries: critical review. Chem. Soc. Rev. 2014, 43, 4714-4727.

(5) Buschmann, H.; Dolle, J.; Berendts, S.; Kuhn, A.; Bottke, P.; Wilkening, M.; Heitjans, P.; Senyshyn, A.; Ehrenberg, H.; Lotnyk, A.; Duppel, V.; Kienle, L.; Janek, J. Structure and dynamics of the fast lithium ion conductor " $\mathrm{Li}_{7} \mathrm{La}_{3} \mathrm{Zr}_{2} \mathrm{O}_{12}$ ". Phys. Chem. Chem. Phys. 2011, 13, 19378-19392.

(6) Rettenwander, D.; Blaha, P.; Laskowski, R.; Schwarz, K.; Bottke, P.; Wilkening, M.; Geiger, C. A.; Amthauer, G. DFT Study of the Role of $\mathrm{Al}^{3+}$ in the Fast Ion-Conductor $\mathrm{Li}_{7-3 x} \mathrm{Al}_{x}{ }^{3+} \mathrm{La}_{3} \mathrm{Zr}_{2} \mathrm{O}_{12}$ Garnet. Chem. Mater. 2014, 26, 2617-2623.

(7) Jin, Y.; McGinn, P. Al-doped $\mathrm{Li}_{7} \mathrm{La}_{3} \mathrm{Zr}_{2} \mathrm{O}_{12}$ synthesized by a polymerized complex method. J. Power Sources 2011, 196, 8683-8687.

(8) Rangasamy, E.; Wolfenstine, J.; Sakamoto, J. The role of $\mathrm{Al}$ and $\mathrm{Li}$ concentration on the formation of cubic garnet solid electrolyte of nominal composition $\mathrm{Li}_{7} \mathrm{La}_{3} \mathrm{Zr}_{2} \mathrm{O}_{12}$. Solid State Ionics 2012, 206, 2832.

(9) Rettenwander, D.; Geiger, C. A.; Amthauer, G. Synthesis and Crystal Chemistry of the Fast Li-Ion Conductor $\mathrm{Li}_{7} \mathrm{La}_{3} \mathrm{Zr}_{2} \mathrm{O}_{12}$ Doped with Fe. Inorg. Chem. 2013, 52, 8005-8009.

(10) Rettenwander, D.; Geiger, C. A.; Tribus, M.; Tropper, P.; Wagner, R.; Tippelt, G.; Lottermoser, W.; Amthauer, G. The solubility and site preference of $\mathrm{Fe}^{3+}$ in $\mathrm{Li}_{7-3 x} \mathrm{Fe}_{x} \mathrm{La}_{3} \mathrm{Zr}_{2} \mathrm{O}_{12}$ garnets. J. Solid State Chem. 2015, 230, 266-271.

(11) Rettenwander, D.; Geiger, C. A.; Tribus, M.; Tropper, P.; Amthauer, G. A Synthesis and Crystal Chemical Study of the Fast Ion Conductor $\mathrm{Li}_{7-3 x} \mathrm{Ga}_{x} \mathrm{La}_{3} \mathrm{Zr}_{2} \mathrm{O}_{12}$ with $x=0.08$ to 0.84. Inorg. Chem. 2014, 53, 6264-6269.

(12) Allen, J. L.; Wolfenstine, J.; Rangasamy, E.; Sakamoto, J. Effect of substitution $(\mathrm{Ta}, \mathrm{Al}, \mathrm{Ga})$ on the conductivity of $\mathrm{Li}_{7} \mathrm{La}_{3} \mathrm{Zr}_{2} \mathrm{O}_{12}$. J. Power Sources 2012, 206, 315-319.

(13) Wolfenstine, J.; Ratchford, J.; Rangasamy, E.; Sakamoto, J.; Allen, J. L. Synthesis and high Li-ion conductivity of Ga-stabilized cubic $\mathrm{Li}_{7} \mathrm{La}_{3} \mathrm{Zr}_{2} \mathrm{O}_{12}$. Mater. Chem. Phys. 2012, 134, 571-575.

(14) El Shinawi, H.; Janek, J. Stabilization-of cubic lithium-stuffed garnets of the type " $\mathrm{Li}_{7} \mathrm{La}_{3} \mathrm{Zr}_{2} \mathrm{O}_{12}$ " by addition of gallium. J. Power Sources 2013, 225, 13-19.

(15) Rangasamy, E.; Wolfenstine, J.; Allen, J.; Sakamoto, J. The effect of $24 c$-site (A) cation substitution on the tetragonal-cubic phase transition in $\mathrm{Li}_{7-x} \mathrm{La}_{3-x} \mathrm{~A}_{x} \mathrm{Zr}_{2} \mathrm{O}_{12}$ garnet-based ceramic electrolyte. J. Power Sources 2013, 230, 261-266.

(16) Rettenwander, D.; Welzl, A.; Cheng, L.; Fleig, J.; Musso, M.; Suard, E.; Doeff, M. M.; Redhammer, G. J.; Amthauer, G. Synthesis, Crystal Chemistry, and Electrochemical Properties of $\mathrm{Li}_{7-2 x} \mathrm{La}_{3} \mathrm{Zr}_{2-x} \mathrm{Mo}_{x} \mathrm{O}_{12}(x=0.1-0.4)$ : Stabilization of the Cubic Garnet Polymorph via Substitution of $\mathrm{Zr}^{4+}$ by $\mathrm{Mo}^{6+}$. Inorg. Chem. 2015, 54, 10440-10449.

(17) Bottke, P.; Rettenwander, D.; Schmidt, W.; Amthauer, G.; Wilkening, M. Ion Dynamics in Solid Electrolytes: NMR Reveals the Elementary Steps of $\mathrm{Li}^{+}$Hopping in the Garnet $\mathrm{Li}_{6.5} \mathrm{La}_{3} \mathrm{Zr}_{1.75} \mathrm{Mo}_{0.25} \mathrm{O}_{12}$. Chem. Mater. 2015, 27, 6571-6582.

(18) Ohta, S.; Kobayashi, T.; Asaoka, T. High lithium ionic conductivity in the garnet-type oxide $\mathrm{Li}_{7-\mathrm{X}} \mathrm{La}_{3}\left(\mathrm{Zr}_{2-\mathrm{X}}, \mathrm{Nb}_{\mathrm{X}}\right) \mathrm{O}_{12}(\mathrm{X}=$ 0-2). J. Power Sources 2011, 196, 3342-3345.

(19) Mukhopadhyay, S.; Thompson, T.; Sakamoto, J.; Huq, A.; Wolfenstine, J.; Allen, J. L.; Bernstein, N.; Stewart, D. A.; Johannes, M. D. Structure and Stoichiometry in Supervalent Doped $\mathrm{Li}_{7} \mathrm{La}_{3} \mathrm{Zr}_{2} \mathrm{O}_{12}$. Chem. Mater. 2015, 27, 3658-3665.

(20) Li, Y. T.; Wang, C. A.; Xie, H.; Cheng, J. G.; Goodenough, J. B. High lithium ion conduction in garnet-type $\mathrm{Li}_{6} \mathrm{La}_{3} \mathrm{ZrTaO}_{12}$. Electrochem. Commun. 2011, 13, 1289-1292.

(21) Buschmann, H.; Berendts, S.; Mogwitz, B.; Janek, J. Lithium metal electrode kinetics and ionic conductivity of the solid lithium ion conductors " $\mathrm{Li}_{7} \mathrm{La}_{3} \mathrm{Zr}_{2} \mathrm{O}_{12}$ " and $\mathrm{Li}_{7-\mathrm{x}} \mathrm{La}_{3} \mathrm{Zr}_{2-\mathrm{x}} \mathrm{Ta}_{\mathrm{x}} \mathrm{O}_{12}$ with garnet-type structure. J. Power Sources 2012, 206, 236-244. 
(22) Cussen, E. J.; Yip, T. W. S. A neutron diffraction study of the $\mathrm{d}^{0}$ and $\mathrm{d}^{10}$ lithium garnets $\mathrm{Li}_{3} \mathrm{Nd}_{3} \mathrm{~W}_{2} \mathrm{O}_{12}$ and $\mathrm{Li}_{5} \mathrm{La}_{3} \mathrm{Sb}_{2} \mathrm{O}_{12}$. J. Solid State Chem. 2007, 180, 1832-1839.

(23) Deviannapoorani, C.; Dhivya, L.; Ramakumar, S.; Murugan, R. Lithium ion transport properties of high conductive tellurium substituted $\mathrm{Li}_{7} \mathrm{La}_{3} \mathrm{Zr}_{2} \mathrm{O}_{12}$ cubic lithium garnets. J. Power Sources 2013, 240, 18-25.

(24) Dhivya, L.; Janani, N.; Palanivel, B.; Murugan, R, $\mathrm{Li}^{+}$transport properties of $\mathrm{W}$ substituted $\mathrm{Li}_{7} \mathrm{La}_{3} \mathrm{Zr}_{2} \mathrm{O}_{12}$ cubic lithium garnets. Aip Adv. 2013, 3.

(25) Murugan, R.; Ramakumar, S.; Janani, N. High conductive yttrium doped $\mathrm{Li}_{7} \mathrm{La}_{3} \mathrm{Zr}_{2} \mathrm{O}_{12}$ cubic lithium garnet. Electrochem. Commun. 2011, 13, 1373-1375.

(26) Xia, Y.; Ma, L.; Lu, H.; Wang, X.-P.; Gao, Y.-X.; Liu, W.; Zhuang, Z.; Guo, L.-J.; Fang, Q.-F. Preparation and enhancement of ionic conductivity in $\mathrm{Al}$-added garnet-like $\mathrm{Li}_{6.8} \mathrm{La}_{3} \mathrm{Zr}_{1.8} \mathrm{Bi}_{0.2} \mathrm{O}_{12}$ lithium ionic electrolyte. Front Mater. Sci. 2015, 9, 366-372.

(27) Murugan, R.; Weppner, W.; Schmid-Beurmann, P.; Thangadurai, V. Structure and lithium ion conductivity of bismuth containing lithium garnets $\mathrm{Li}_{5} \mathrm{La}_{3} \mathrm{Bi}_{2} \mathrm{O}_{12}$ and $\mathrm{Li}_{6} \mathrm{SrLa}_{2} \mathrm{Bi}_{2} \mathrm{O}_{12}$. Mater. Sci. Eng., B 2007, 143, 14-20.

(28) Gao, Y. X.; Wang, X. P.; Wang, W. G.; Zhuang, Z.; Zhang, D. M.; Fang, Q. F. Synthesis, ionic conductivity, and chemical compatibility of garnet-like lithium ionic conductor $\mathrm{Li}_{5} \mathrm{La}_{3} \mathrm{Bi}_{2} \mathrm{O}_{12}$. Solid State Ionics 2010, 181, 1415-1419.

(29) Gao, Y. X.; Wang, X. P.; Sun, Q. X.; Zhuang, Z.; Fang, Q. F. Electrical properties of garnet- like lithium ionic conductors $\mathrm{Li}_{5+\mathrm{x}} \mathrm{Sr}_{\mathrm{x}} \mathrm{La}_{3-\mathrm{x}} \mathrm{Bi}_{2} \mathrm{O}_{12}$ fabricated by spark plasma sintering method. Front Mater. Sci. 2012, 6, 216-224.

(30) Gao, Y. X.; Zhuang, Z.; Lu, H.; Wang, X. P.; Fang, Q. F. Relaxation Model of Lithium Ions in the Garnet-like $\mathrm{Li}_{5} \mathrm{La}_{3} \mathrm{Bi}_{2} \mathrm{O}_{12}$ Lithium-lon Conductor. Solid State Phenom. 2012, 184, 116-121.

(31) Aono, H.; Sugimoto, E.; Sadaoka, Y.; Imanaka, N.; Adachi, G. Ionic-Conductivity of Solid Electrolytes Based on Lithium Titanium Phosphate. J. Electrochem. Soc. 1990, 137, 1023-1027.

(32) Knauth, P. Inorganic solid Li ion conductors: An overview. Solid State Ionics 2009, 180, 911-916.

(33) Kamaya, N.; Homma, K.; Yamakawa, Y.; Hirayama, M.; Kanno, R.; Yonemura, M.; Kamiyama, T.; Kato, Y.; Hama, S.; Kawamoto, K.; Mitsui, A. A lithium superionic conductor. Nat. Mater. 2011, 10, 682686.

(34) Zeier, W. G. Structural limitations for optimizing garnet-type solid electrolytes: a perspective. Dalton T 2014, 43, 16133-16138.

(35) Zeier, W. G.; Zhou, S. L.; Lopez-Bermudez, B.; Page, K.; Melot, B. C. Dependence of the Li-Ion Conductivity and Activation Energies on the Crystal Structure and Ionic Radii in $\mathrm{Li}_{6} \mathrm{MLa}_{2} \mathrm{Ta}_{2} \mathrm{O}_{12}$. ACS Appl. Mater. Interfaces 2014, 6, 10900-10907.

(36) Miara, L. J.; Ong, S. P.; Mo, Y. F.; Richards, W. D.; Park, Y.; Lee, J. M.; Lee, H. S.; Ceder, G. Effect of Rb and Ta Doping on the Ionic Conductivity and Stability of the Garnet $\mathrm{Li}_{7+2 x-y}\left(\mathrm{La}_{3-x} \mathrm{Rb}_{x}\right)\left(\mathrm{Zr}_{2-y} \mathrm{Ta}_{y}\right)$ $\mathrm{O}_{12}(0 \leq x \leq 0.375,0 \leq y \leq 1)$ Superionic Conductor: A First Principles Investigation. Chem. Mater. 2013, 25, 3048-3055.

(37) Shannon, R. D. Revised Effective Ionic-Radii and Systematic Studies of Interatomic Distances in Halides and Chalcogenides. Acta Crystallogr., Sect. A: Cryst. Phys., Diffr., Theor. Gen. Crystallogr. 1976, 32, 751-767.

(38) Rodriguez-Carvajal, J. Magnetic structure determination from powder diffraction using the program FullProf. Applied Crystallography 2000, 30-36.

(39) Liu, C.; Rui, K.; Shen, C.; Badding, M. E.; Zhang, G. X.; Wen, Z. $\mathrm{Y}$. Reversible ion exchange and structural stability of garnet-type $\mathrm{Nb}$ doped $\mathrm{Li}_{7} \mathrm{La}_{3} \mathrm{Zr}_{2} \mathrm{O}_{12}$ in water for applications in lithium batteries. $J$. Power Sources 2015, 282, 286-293.

(40) Orera, A.; Larraz, G.; Rodriguez-Velamazan, J. A.; Campo, J.; Sanjuan, M. L. Influence of $\mathrm{Li}^{+}$and $\mathrm{H}^{+}$Distribution on the Crystal Structure of $\mathrm{Li}_{7-x} \mathrm{H}_{x} \mathrm{La}_{3} \mathrm{Zr}_{2} \mathrm{O}_{12}(0 \leq x \leq 5)$ Garnets. Inorg. Chem. 2016, 55, 1324-1332.

(41) Cheng, L.; Wu, C. H.; Jarry, A.; Chen, W.; Ye, Y. F.; Zhu, J. F.; Kostecki, R.; Persson, K.; Guo, J. H.; Salmeron, M.; Chen, G. Y.;
Doeff, M. Interrelationships among Grain Size, Surface Composition, Air Stability, and Interfacial Resistance of Al-Substituted $\mathrm{Li}_{7} \mathrm{La}_{3} \mathrm{Zr}_{2} \mathrm{O}_{12}$ Solid Electrolytes. ACS Appl. Mater. Interfaces 2015, 7, 17649-17655.

(42) Jin, Y.; McGinn, P. J. $\mathrm{Li}_{7} \mathrm{La}_{3} \mathrm{Zr}_{2} \mathrm{O}_{12}$ electrolyte stability in air and fabrication of a $\mathrm{Li} / \mathrm{Li}_{7} \mathrm{La}_{3} \mathrm{Zr}_{2} \mathrm{O}_{12} / \mathrm{Cu}_{0.1} \mathrm{~V}_{2} \mathrm{O}_{5}$ solid-state battery. J. Power Sources 2013, 239, 326-331.

(43) Larraz, G.; Orera, A.; Sanjuan, M. L. Cubic phases of garnet-type $\mathrm{Li}_{7} \mathrm{La}_{3} \mathrm{Zr}_{2} \mathrm{O}_{12}$ : the role of hydration. J. Mater. Chem. A 2013, 1, 1141911428.

(44) Larraz, G.; Orera, A.; Sanz, J.; Sobrados, I.; Diez-Gómez, V.; Sanjuán, M. L. NMR study of Li distribution in $\mathrm{Li}_{7-\mathrm{x}} \mathrm{H}_{\mathrm{x}} \mathrm{La}_{3} \mathrm{Zr}_{2} \mathrm{O}_{12}$ garnets. J. Mater. Chem. A 2015, 3, 5683-5691.

(45) Wagner, R.; Redhammer, G. J.; Rettenwander, D.; Senyshyn, A.; Schmidt, W.; Wilkening, M.; Amthauer, G. Crystal Structure of Garnet-Related Li-Ion Conductor $\mathrm{Li}_{7-3 x} \mathrm{Ga}_{x} \mathrm{La}_{3} \mathrm{Zr}_{2} \mathrm{O}_{12}$ : Fast Li-Ion Conduction Caused by a Different Cubic Modification? Chem. Mater. 2016, 28, 1861-1871.

(46) Rettenwander, D.; Redhammer, G.; Preishuber-Pflügl, F.; Cheng, L.; Miara, L.; Wagner, R.; Welzl, A.; Suard, E.; Doeff, M. M.; Wilkening, M.; Fleig, J.; Amthauer, G. Structural and Electrochemical Consequences of $\mathrm{Al}$ and $\mathrm{Ga}$ Cosubstitution in $\mathrm{Li}_{7} \mathrm{La}_{3} \mathrm{Zr}_{2} \mathrm{O}_{12}$ Solid Electrolytes. Chem. Mater. 2016, 28, 2384-2392.

(47) Wagner, R.; Redhammer, G. J.; Rettenwander, D.; Tippelt, G.; Welzl, A.; Taibl, S.; Fleig, J.; Franz, A.; Lottermoser, W.; Amthauer, G. Fast Li-Ion-Conducting Garnet-Related $\mathrm{Li}_{7-3 x} \mathrm{Fe}_{x} \mathrm{La}_{3} \mathrm{Zr}_{2} \mathrm{O}_{12}$ with Uncommon I $\overline{4} 3 d$ Structure. Chem. Mater. 2016, 28, 5943-5951.

(48) Ma, C.; Rangasamy, E.; Liang, C.; Sakamoto, J.; More, K. L.; Chi, M. Excellent stability of a lithium-ion-conducting solid electrolyte upon reversible $\mathrm{Li}(+) / \mathrm{H}(+)$ exchange in aqueous solutions. Angew. Chem., Int. Ed. 2015, 54, 129-33.

(49) Tietz, F.; Wegener, T.; Gerhards, M. T.; Giarola, M.; Mariotto, G. Synthesis and Raman micro-spectroscopy investigation of $\mathrm{Li}_{7} \mathrm{La}_{3} \mathrm{Zr}_{2} \mathrm{O}_{12}$. Solid State Ionics 2013, 230, 77-82.

(50) Thompson, T.; Wolfenstine, J.; Allen, J. L.; Johannes, M.; Huq, A.; David, I. N.; Sakamoto, J. Tetragonal vs. cubic phase stability in Al free Ta doped $\mathrm{Li}_{7} \mathrm{La}_{3} \mathrm{Zr}_{2} \mathrm{O}_{12}$ (LLZO). J. Mater. Chem. A 2014, 2, 13431-13436.

(51) Pasierb, P.; Komornicki, S.; Rokita, M.; Rękas, M. Structural properties of $\mathrm{Li}_{2} \mathrm{CO}_{3}-\mathrm{BaCO}_{3}$ system derived from IR and Raman spectroscopy. J. Mol. Struct. 2001, 596, 151-156.

(52) Peltzer, D.; Múnera, J.; Cornaglia, L. Operando Raman spectroscopic studies of lithium zirconates during $\mathrm{CO}_{2}$ capture at high temperature. RSC Adv. 2016, 6, 8222-8231.

(53) Koura, N.; Kohara, S.; Takeuchi, K.; Takahashi, S.; Curtiss, L. A.; Grimsditch, M.; Saboungi, M.-L. Alkali carbonates: Raman spectroscopy, ab initio calculations, and structure. J. Mol. Struct. 1996, 382, 163-169.

(54) Afyon, S.; Krumeich, F.; Rupp, J. L. M. A shortcut to garnet-type fast Li-ion conductors for all-solid state batteries. J. Mater. Chem. A 2015, 3, 18636-18648.

(55) Wang, Y. X.; Lai, W. Phase transition in lithium garnet oxide ionic conductors $\mathrm{Li}_{7} \mathrm{La}_{3} \mathrm{Zr}_{2} \mathrm{O}_{12}$ : The role of $\mathrm{Ta}$ substitution and $\mathrm{H}_{2} \mathrm{O}$ / $\mathrm{CO}_{2}$ exposure. J. Power Sources 2015, 275, 612-620.

(56) Xia, W.; Xu, B.; Duan, H.; Guo, Y.; Kang, H.; Li, H.; Liu, H. Ionic Conductivity and Air Stability of Al-Doped $\mathrm{Li}_{7} \mathrm{La}_{3} \mathrm{Zr}_{2} \mathrm{O}_{12}$ Sintered in Alumina and Pt Crucibles. ACS Appl. Mater. Interfaces 2016, 8, 5335-42.

(57) Galven, C.; Dittmer, J.; Suard, E.; Le Berre, F.; Crosnier-Lopez, M.-P. Instability of Lithium Garnets against Moisture. Structural Characterization and Dynamics of $\mathrm{Li}_{7-\mathrm{x}} \mathrm{H}_{\mathrm{x}} \mathrm{La}_{3} \mathrm{Sn}_{2} \mathrm{O}_{12}$ and $\mathrm{Li}_{5-\mathrm{x}} \mathrm{H}_{\mathrm{x}} \mathrm{La}_{3} \mathrm{Nb}_{2} \mathrm{O}_{12}$. Chem. Mater. 2012, 24, 3335-3345.

(58) Galven, C.; Fourquet, J. L.; Crosnier-Lopez, M. P.; Le Berre, F. Instability of the Lithium Garnet $\mathrm{Li}_{7} \mathrm{La}_{3} \mathrm{Sn}_{2} \mathrm{O}_{12}: \mathrm{Li}^{+} / \mathrm{H}^{+}$Exchange and Structural Study. Chem. Mater. 2011, 23, 1892-1900.

(59) Gam, F.; Galven, C.; Bulou, A.; Le Berre, F.; Crosnier-Lopez, M. P. Reinvestigation of the Total $\mathrm{Li}^{+} / \mathrm{H}^{+}$Ion Exchange on the GarnetType $\mathrm{Li}_{5} \mathrm{La}_{3} \mathrm{Nb}_{2} \mathrm{O}_{12}$. Inorg. Chem. 2014, 53, 931-934. 
(60) Li, Y. T.; Han, J. T.; Wang, C. A.; Xie, H.; Goodenough, J. B. Optimizing $\mathrm{Li}^{+}$conductivity in a garnet framework. J. Mater. Chem. 2012, 22, 15357-15361. 